\title{
A phylogenetic study of floral morphology of some members of Asclepiadaceae R.Br.
}

Sanjit Sinha and Amal Kumar Mondal*

Department of Botany and Forestry, UGC-DRS-SAP Department, Plant Taxonomy, Biosystematics and Molecular Taxonomy Laboratory, Vidyasagar University, Midnapore-721102, West Bengal, India.

Received: January 12, 2017; Accepted: January 27, 2017

\begin{abstract}
Floral morphological diversity and phylogenetic relationship were studied in the family Asclepiadaceae. This family characterized by unique features that contributes to extreme floral complexity and diversity. In this paper, we used preliminary phylogenetic hypothesis for the family Asclepiadaceae to explore the mode of diversification in pollinarium and coronal structure. The occurance, size, shape, position, orientation of pollinia, mode of pollination and the presence of form of coralline corona and gynostegial corona were studied for similarity indices between two subfamilies Periplocoideae and Asclepiadoideae.
\end{abstract}

Key words: Asclepiadaceae; Periplocoideae; pollinia; coralline corona; gynostegial corona; phylogenetic hypothesis.

\section{Introduction}

Asclepiadaceae includes some 250 genera and over 2000 species, widespread in tropical and subtropical regions, especially in Africa and southern South America, with a moderate representation in northern and southeastern Asia. They are herbs, shrubs, or rarely tree like, with milky or, less often, clear latex. The family Asclepiadaceae is commonly known as "Milkweed family". The Asclepiadaceae are mostly herbs and shrubs with white sap, many of which are lianous and some of which are cactus like succulents with reduced leaves. The leaves are simple and nearly always opposite or whorled; minute stipules are present. The flowers are bisexual, nearly always actinomorphic, and usually include an elaborate crown or corona of nectariferous appendages between the corolla and sexual parts. The calyx consists of 5 distinct or basally connate sepals. The inner perianth is a 5-lobed sympetalous corolla. The androecium and gynoecium are nearly always adnate into a gynostegium with five highly modified stamens and a massive, 5-lobed stigma. The anthers usually produce paired sacs of pollen called pollinia that are transferred as a unit during pollination. The gynoecium consists of a single compound pistil of two nearly distinct carpels that are separate at the level of the ovaries and styles and are united only by a single massive stigma. The ovaries are distinct, nearly always superior, and each has a single locule with numerous marginal ovules. The fruit is a follicle. Seeds usually have a tuft of hairs at one end. The most interesting feature of Asclepediaceae is the presence of pollinia. Pollinium, or plural pollinia, is a coherent mass of pollen grains. The packaging of pollen into a compact unit known as the pollinium, which together with accessory structure for attachment to pollinator comprises pollination was undoubtedly a key innovation in the evolutionary history of the family Asclepiadaceae. They are the product of only one anther, but are transferred, during pollination, as a single unit. This is also seen in case of orchids. This family is characterized by five stamens usually inserted at base of corolla tube and adhering to stigma head to form gynostegium. The filaments are usually connate to form a tube enclosing ovaries. Anthers are 4-celled in case of the subfamilies Periplocoideae and Secamonoideae or 2-celled in case of Asclepiadoideae, often with a membranous apical appendage. The pollen tetrads may be contained loosely on a saturate translator with a basal corpuscular as in Periplocoideae or the pollen may be united into waxy pollinia, each attached through a caudices (stalk) to the retinaculum (gland) between adjacent anthers to form a

\section{${ }^{*}$ Corresponding Author:}

\section{Dr. Prof. Amal Kumar Mondal,}

Professor in Botany \& HOD \& Coordinator UGC-DRS-SAP, Department of Botany \& Forestry,

Vidyasagar University, Midnapore-721 102, West Bengal, India.

E-mail: amalcaebotvu@gmail.com pollination. The number of pollinia per pollinarium may be 2 as in case of Asclepiadoideae or 4 as in case of Secamonoideae. Asclepediaceae has been classified into three subfamilies viz. Periplocoideae, Secamonoideae and Asclepiadoideae. In particular anther and pollinium orientation are important, but little-studied characters. It is not known whether various instances of these states are achieved in the same way. In spite of this importance, relatively little study has been devoted to understanding the variation encountered in these characters. Some of these characters are related to the orientation of the anther, others to the nature of pollinia themselves or of their associated structures (stalks). Variation in pollinia includes differences in numbers and packaging. Variation in another position on the column has been recognized as a systematically important feature at least since the time of Bentham (1881) in orchids. Similarly, the position of the pollinia within the anther (as seen in a transverse section) has had a similarly long use in systematic, again known at least since the time of Bentham (1881). Among the Angiosperms the two families namely the Asclepiadaceae and Orchidaceae where pollen formed with waxy pollen sacs. The formation of waxy pollen sacs in members of both the families is coincidentally associated with the evolution of sophisticated mechanism of insect pollination. Much work has been done on pollen grains of other families; this palynological data is of great value in solving the problems related to systematic and for pollen fossil records (Franks and Watson, 1963). The pollen grains in Asclepiadaceae are all agglutinated, forming variously shaped waxy pollen sacs which are called pollinia, and in members of Periplocaceae pollen are in tetrads or pollen agglutinated to form pollen massulae. The Asclepiadaceae of sensu lato of Robert Brown has two sub families; Periplocoideae and Cyananchoideae. Bullock (1956), Santapau and Irani (1962), and Hutchinson (1973) have preferred to treat the sub families as families, Periplocoideae as independent family, the Periplocaceae Schltr., mainly because, that this sub family has free stamens, spathulate pollen carriers and granular pollen and Cynanchoideae as Asclepiadaceae sensu strict because of connate stamens, and a waxy pollinia. The flowers of Asclepiadoideae, commonly known as 'asclepiads' (family Apocynaceae sensu Endress and Bruyns, 2000; Endress et al., 2007), caught the attention of early botanists, mainly because of their extremely elaborate floral arrangements (Brown, 1833; Corry, 1884; Endress, 1994). Several aspects of these arrangements involve a marked synorganization which is fairly uniform within and exclusive to 
this subfamily. The more outstanding features include: (1) a corona, a sterile whorl additional to the corolla; (2) a gynostegium, an organ formed by the post-genital fusion of androecium and gynoecium that is differentiated into five sectors arranged in a revolver-like system, in which each sector constitutes a pollination unit which comprises a guide rail, a stigmatic chamber and the receptive area; and (3) pollinaria, constituted by two pollinia from adjacent anthers and linked by a solid bridge of stigmatic secretions, the translator apparatus (Bookman, 1981; Fallen, 1986; Endress, 1994; Kunze, 1981, 1996; Verhoeven and Venter, 2001). While the general pollinia are extremely conservative, floral diversity is driven by differences in these features and their relationship to each other (Endress, 1994). The purpose of this study is to provide information concerning the pollinium and pollinium wall structure of the three subfamilies according to our own observations, and is not meant to be a comprehensive palynological study.

\section{Materials and Methods}

Fresh flowers in the form of inflorescence were collected between 8-11am and pollinia were lifted out from freshly opened flowers. The pollinia collected at randomly and measurements were taken by light microscope (LeicaDM1000). We have selected nine plants from South West Bengal viz Calotropis gigantea (L.) W.T. Aiton., Calotropis procera (Aiton) W.T. Aiton. Daemia extensa (Jacq.) R.Br., Dregea volubilis (Linn.f.) Benth., Gymnema sylvestres R.Br., Oxystelma esculentum (L.fil.) R.Br., Tylophora indica (Burm.f.) Merr., Tylophora tenuis blume. and Holostemma ada-kodien Schult Hemidesmus indicus (L.) R. Br. Cryptostegia grandiflora (Roxb.) R. Br. Cryptolepis buchanani Romer \& Schult. Flowers of nine species were randomly collected from different populations [Table 1] and preserved in $50 \%$ ethyl alcohol. For scanning electron microscope, the raw materials were fixed in the mixture of ethyle alcohol and glacial acetic acid which is dehydrated in a graded ethyl alcohol series to absolute ethyl alcohol and dried. Dried specimens were coated with gold and examined using SEM (QUANTA 200) From Bose Institute, Kakurgachi, Kolkata and IIT kharagpur. Mean value with standard deviation and standard error of Length and breadth of pollinium sac, translator and corpusculum were compared among different species with the help of statistical software [Origin 6.1 (version)]. Structural data were obtained from a lesser extent on our observation and twenty-six characters were coded and scored for the twelve genera for a preliminary phylogenetic analysis. The quantitative measurements of pollinaria were obtained by the Leica Microscope. Character statements were coded for exemplar taxa sample for a preliminary phylogenetic analysis. The 12 taxa of this family Asclepiadaceae were included in the matrix, which was subsequently analysed using persimony methods. A phylogenetic analysis was carried out by NTsys software [ver 2.2]. Different morphological parts were transferred to the microscope slide and covered with a glass cover slip then we examine with bright field microscope. Some low magnification images were taken with a light microscope (Olympus), Phase contrast microscope (Leica DM - 1000). All comparison was made by analysis of the dendrogram which is made by UPGMA on the basis of different micro-morphological characters.

\section{Results}

A. Morphological study of selected plant taxa of Asclepiadaceae

\section{Calotropis procera (Aiton) W.T. Aiton. (Fig. 1)}

Woody erect shrub to $2.5 \mathrm{~m}$. Stems cylindrical up to $1 \mathrm{~cm}$ diameter on foliage bearing parts, glabrous; internodes up to 6 $\mathrm{cm}$ long, with a grey-green pruinose bloom. Leaves elliptic, up to $18 \mathrm{~cm}$ long and $15 \mathrm{~cm}$ wide; above venation obscure; below with 6 major secondary veins per side of midrib prominent; tip acute to rounded; base cordate to auriculate; petiole 3-4 $\mathrm{mm}$ long, 4-5 mm wide; extrafloralnectaries 20-27 at lamina base. Cyme up to $10 \mathrm{~cm}$ long with 1-12 fascicles; bracts lanceolate, 8-13 mm long, 3.5-6 mm wide, glabrous or with scattered to sparse indumentum, tip shortly acuminate; peduncle up to 3.5 $\mathrm{cm}$ long, 2-7 $\mathrm{mm}$ diameter, glabrous, or with scattered to sparse indumentum and with a grey-green pruinose bloom. Flowers campanulate, $13-20 \mathrm{~mm}$ long, 23-25 mm diameter, with a slightly sweet scent; pedicels $15-27 \mathrm{~mm}$ long, 1-2.5 mm diameter, cream, glabrous or with scattered to sparse indumentum. Sepals ovate, $7-8 \mathrm{~mm}$ long, c. $5 \mathrm{~mm}$ wide, cream, glabrous, base of each sinus with 3-9 glands. Corolla tube cream, c. $5 \mathrm{~mm}$ long, $10-11 \mathrm{~mm}$ diameter; lobes lanceolateovate, 9-10 $\mathrm{mm}$ long, 9-10 $\mathrm{mm}$ wide, cream with purple tips internally, cream externally. Staminal corona 4-5 mm long, 9-10 $\mathrm{mm}$ diameter; each lobe c. $6 \mathrm{~mm}$ long, c. $1 \mathrm{~mm}$ wide at middle and $4 \mathrm{~mm}$ wide at outer edges, edges purple, cream next to stamina column. Staminal column c. $9 \mathrm{~mm}$ long and $5 \mathrm{~mm}$ diameter, cream; anther appendages truncate-obtuse, c. $3 \mathrm{~mm}$ long and $3.5 \mathrm{~mm}$ wide; alar fissure $0.75-1 \mathrm{~mm}$ long. Style-head c. $5 \mathrm{~mm}$ diameter, cream, extending $1 \mathrm{~mm}$ above anthers. Carpels c. $6 \mathrm{~mm}$ long and $3 \mathrm{~mm}$ wide. Pollinarium 2-2.1 $\mathrm{mm}$ long, $0.9-1 \mathrm{~mm}$ wide; pollinia oblong, $1.35-1.45 \mathrm{~mm}$ long, $0.55-$ $0.6 \mathrm{~mm}$ wide; corpusculum oblong, $0.45 \mathrm{~mm}$ long, 0.1-0.15 $\mathrm{mm}$ wide, with a wing of tissue around edges that is a continuation of the caudicle tissue; caudicles $0.35-0.4 \mathrm{~mm}$ long, $0.05 \mathrm{~mm}$ wide. Follicle 10-12 cm long, 6-7 cm wide. Seed 8-8.5 $\mathrm{mm}$ long, c. $5 \mathrm{~mm}$ wide; coma 25-28 mm long, white.

Flowering Time: June to August

\section{Calotropis gigantea (L.) W.T. Aiton. (Fig. 2)}

Woody, erect shrub to $4 \mathrm{~m}$. Stems cylindrical, up to $6 \mathrm{~cm}$ diameter on foliage bearing parts, glabrous; internodes up to 5 $\mathrm{cm}$ long, with glaucous white bloom. Leaves petiolate; lamina elliptic to oblong, up to $10 \mathrm{~cm}$ long and $8 \mathrm{~cm}$ wide, coriaceous, somewhat fleshy, glabrous; above venation obscure; below with 6 or 7 secondary veins per side of midrib prominent; tip acute to rounded; base cordate to auriculate; sessile or with petiole $0.2-0.7 \mathrm{~mm}$ long, c. $0.2 \mathrm{~mm}$ wide; extrafloralnectaries 19-20 at lamina base. Cyme up to $10 \mathrm{~cm}$ long with 1-3 fascicles of flowers; bracts lanceolate, 6-7 $\mathrm{mm}$ long, $2-3 \mathrm{~mm}$ wide, with scattered indumentum, tip acute; peduncle up to $3.2 \mathrm{~cm}$ long, 2-4 $\mathrm{mm}$ diameter, waxy glaucous or with scattered indumentum. Flower campanulate, 24-25 mm long, 30-55 mm diameter; pedicels $2.5-4 \mathrm{~cm}$ long, 1-2.3 mm diameter, with scattered indumentum. Sepals lanceolate-ovate to ovate, 5-7 $\mathrm{mm}$ long, c. $4 \mathrm{~mm}$ wide, ciliate, base of each sinus lacking extrafloralnectaries. Corolla tube 5-6 mm long, $14-15 \mathrm{~mm}$ diameter, glabrous; lobes ovate, fleshy, 15-17 mm long, 10-11 $\mathrm{mm}$ wide, glabrous, tips acute. Staminal corona 11-12 mm long, 14-15 mm diameter, consisting of 5 lobes fused for entire length to staminal column; each lobe broadly flanged, 11-12 $\mathrm{mm}$ long, $6-6.5 \mathrm{~mm}$ wide, with the base elongated into an upturned hook c. $5 \mathrm{~mm}$ long. Staminal column 14-15 mm long, 4.6-5 $\mathrm{mm}$ diameter; anther appendages truncate, $0.5 \mathrm{~mm}$ long and $2 \mathrm{~mm}$ wide; alar fissure $1.3 \mathrm{~mm}$ long. Style-head $2 \mathrm{~mm}$ diameter. Carpels 9-10 mm long, 2-2.1 mm wide. Pollinarium c. $2.5 \mathrm{~mm}$ long and $2.5 \mathrm{~mm}$ wide; pollinia oblong, $1.6-1.7 \mathrm{~mm}$ long, 0.6-0.65 mm wide; corpusculum c. $0.6 \mathrm{~mm}$ long and 0.32 $\mathrm{mm}$ wide; caudicles c. $0.3 \mathrm{~mm}$ long and $0.1 \mathrm{~mm}$ wide. Follicle $7-10 \mathrm{~cm}$ long and 2.5-4 cm wide, glabrous. Seeds 8-9 $\mathrm{mm}$ long, 5.5-6 mm wide; coma 20-25 mm long, white.

Flowering Time: Throughout the year mainly June to September. 


\section{Dregea volubilis (Linn.f.) Benth. (Fig 3)}

Lianas to $12 \mathrm{~m}$. Branches pale gray, lenticellate, branchlets green, smooth. Petiole $2.5-6 \mathrm{~cm}$; leaf blade broadly ovate or suborbicular, 7-18 $\times 4-17 \mathrm{~cm}$, glabrous or soft pubescent, base shallowly cordate, apex acute or short acuminate; lateral veins ca. 4 pairs. Inflorescences pendent, many flowered; peduncle 2-6 cm, slender, puberulent. Pedicel 2-2.5 cm; flowers green or yellowish green, fragrant. Sepals ovate-oblong, 2.5-3 mm, pubescent, ciliate. Corolla glabrous; lobes broadly ovate, 6-12 $\times 5-12 \mathrm{~mm}$, obtuse, ciliate. Corona yellowish green, 4-4.5 mm in diam. Anther appendages white; pollinia oblong. Ovaries pilose. Follicles narrowly ovoid, $10-15 \times 3-4 \mathrm{~cm}$, longitudinally wrinkled-striate or irregularly ribbed. Seeds ovate, ca. $1.2 \mathrm{~cm} \times$ $6 \mathrm{~mm}$, flattened, marginate; coma ca. $4.5 \mathrm{~cm}$.

Flowering Time: April to September

\section{Oxystelma esculentum (L.fil.) R. Br. (Fig 4)}

Twining shrubs Leaves simple, opposite, 4-8 x 0.5-2 cm, oblong to linear, subcoriaceous, base truncate, apex mucronate; petiole ca. $1 \mathrm{~cm}$. Flower(s) usually paired, axillary, solitary or in lax racemes; peduncle $6-15 \mathrm{~cm}$; bracts deciduous; pedicel ca. $1 \mathrm{~cm}$. Calyx cupular; lobes equal, ovate, imbricate, 4 $\mathrm{mm}$, chartaceous, glabrous, acute. Corolla white or pink with dark pink stripes within, $2.5 \mathrm{~cm}$ across, rotate to angulate; lobes triangular, united at the mid half, valvate, $2 \mathrm{~cm}$, shortly overlapping to right in bud, chartaceous, ciliate, acute, recurved. Pollinia pendulous; pollinial bags oblong, $1.3 \mathrm{~mm}$; caudicle $0.2 \mathrm{~mm}$. Corona double; outer corolline, annular, pubescent at the base of corolla within; inner staminal, basally inflated, $5 \mathrm{~mm}$; staminal column $7 \mathrm{~mm}$. Ovaries globose, 3 $\mathrm{mm}$; placenta bifurcate; style $4 \mathrm{~mm}$. Follicle $5 \times 2 \mathrm{~cm}$, inflated, mucronate; seeds ovate, $2.5 \times 2 \mathrm{~mm}$, base rounded, apex pointed; coma silky, dull white.

Flowering Time: July to September.

\section{Cryptostegia grandiflora (Roxb.) R. Br. (Fig 5)}

C. grandiflora is a perennial woody climber or vine, which can also grow as a sub-shrub in open situations, with milky-white latex. Stems with numerous small lenticels; slender and twining around each other or supporting plants. Rapid elongation of the shoots during favorable conditions results in long, unbranched whips, up to $5 \mathrm{~m}$ long, with green smooth bark. Old vines can climb 20-30 m into the upper storey canopy, with thick stems and scaly, greyish-brown bark. Roots robust, reddish-brown and which can penetrate up to $12 \mathrm{~m}$; producing yellow, fibrous feeding roots. Leaves glossy, dark green, glabrous, paler green below, in well separated pairs, up to 10 $\mathrm{cm}$ long, $2-3 \mathrm{~cm}$ wide; tip acute narrowing abruptly at the base into a short stalk with a prominent reddish-purple midvein. Inflorescence a cyme of 1-2 fascicles. Flowers large and showy, white internally, pinkish-white to lilac externally; corolla funnel- or trumpet-shaped, 5-6 cm long, 5-8 cm diameter, with 5 pointed, broadly spreading lobes. Corolline corona of 5 bilobed filaments in throat of tube. Staminal column 2-3 mm long, 3-4 mm wide. Style head conical, $3.5 \times 2.5 \mathrm{~mm}$; ovaries 4 x $2 \mathrm{~mm}$. Fruits (follicles), large green pods, $10-15$ x 3-4 cm, produced in pairs horizontally opposed and diverging from the tip of a short common stalk; sharply 3 -angled and tapering to a long beak. Pod containing 200-350 large (5-10 x 1.5-3 mm), ovate, brown seeds with a tuft (coma) of long (19-38 mm), fine, silky-white hairs at one end.

Flowering Time: Throughout the year but mainly June to August.

\section{Gymnema sylvestre R.Br. (Fig 6)}

G. sylvestre a slow growing, perennial, woody climber. The plant is a large, more or less pubescent, woody climber. The leaves are opposite, usually elliptic or ovate $(1.25-2.0$ inch x $0.5-1.25$ inch). Flowers are small, yellow, in axillary and lateral umbel in cymes; Follicles are terete and lanceolateupto 3 inches in length. The Calyx-lobes are long, ovate, obtuse and pubescent. Corolla is pale yellow campanulate, valvate, corona single, with 5 fleshy scales. Scales adnate to throat of corolla tube between lobes; Anther connective produced into a memberanous tip, pollinia 5, erect, carpels 2, unilocular; locules many ovuled. Follicles paired, widely divaricate, narrowly lanceolate in outline. Seeds comose.

Flowering time: June to August

\section{Cryptolepis buchanani Romer \& Schult. (Fig 7)}

Shrubs or woody lianas. Leaves abaxiallyglaucous, Leaf blade $10-18 \times 4.5-7.5 \mathrm{~cm}$, Cymes terminal, apparently axillary or extra-axillary, pedunculate. Calyx with 5 to 10 basal glands. Flower buds cylindric, apex caudate-acuminate. Corolla salverform; tube short cylindric or campanulate; lobes overlapping to right. Corona lobes inserted near middle of corolla tube, linear or ovate, free from filaments. Filaments broad below, narrow above; anthers connate, adnate to stigma head; pollen tetrads in masses, solitary in each anther cell, pollen carriers spatulate, erect. Stigma head broadly conical. Follicles paired, widely divaricate, narrowly lanceolate in outline, follicles $6.5-8 \times 1-2 \mathrm{~cm}$. Seeds comose.

Flowering Time: June to August.

\section{Tylophora indica (Burm.f.) Merr. (Fig 8A \& 8B)}

Plants usually perennial twining, less oftenherbaceous and/or erect. Leaves opposite. Inflorescences extra-axillary, rarely terminal, mostly with several cymules born along a simple or branched, often zigzag rachis, less often umbel-like; raceme like or sometimes umbel-like. Calyx with basal glands. Corolla rotate or subrotate, deeply 5-lobed; lobes, narrowly overlapping to right to subvalvate, often distinctly veined. Corona lobes usually erect, turgid, adnate to and not exceeding gynostegium, rarely spreading, circular. Anthers short, appendages arching over stigma head; pollinia 2 per pollinarium, horizontal, suberect, rarely erect, caudicles ascending or suberect, retinaculum small. Stigma head depressed, flattened or concave, rarely longer than anthers. Follicles oblong-lanceolate or fusiform. Seeds comose.

Flowering Time: June to September.

\section{Tylophora tenuis blume. (Fig 9)}

Plants usually perennial twining, less oftenherbaceous and/or erect. Leaves opposite. Flowers small pinkish to brownish in colour, pedicel long, capillary. Inflorescences extra-axillary, rarely terminal, mostly with several cymules born along a simple or branched, often zigzag rachis, less often umbel-like; raceme like or sometimes umbel-like, glabrous. Calyx with basal glands. Sepals glabrous, ovate. Corolla rotate or subrotate, deeply 5-lobed; lobes narrowly overlapping to right to subvalvate, often distinctly veined. Corona lobes usually erect, turgid, and not exceeding gynostegium, rarely spreading, circular. Anthers short, appendages arching over stigma head; pollinia 2 per pollinarium, horizontal, suberect, rarely erect, caudicles ascending or suberect, retinaculum small. Stigma head depressed, flattened or concave, rarely longer than anthers. Follicles oblong-lanceolate or fusiform. Seeds comose. Flowering Time: May to July.

\section{Holostemma ada-kodien Schult. (Fig 10)}

Lianas large, herbaceous or woody. Stems to $8 \mathrm{~m}$, much branched, glabrous. Petiole $2-6 \mathrm{~cm}$; leaf blade ovate-cordate, 5-12 $\times 2-8 \mathrm{~cm}$, glabrous except for puberulent abaxial veins. Inflorescences extra-axillary, umbel-like or short raceme like, occasionally branched, shorter than leaves, usually few flowered Peduncle $2.5-5 \mathrm{~cm}$. Pedicel longer than peduncle. 
Flowers large. Calyx without glands Sepals ovate, $3 \mathrm{~mm}$. Corolla subrotate, white to yellowish white, purplish crimson inside, $2-3.5 \mathrm{~cm}$ in diam., divided ca. $2 / 3$ way to base; lobes ovate-oblong, $0.8-1.6 \mathrm{~cm}$.; lobes overlapping to right. Corona shallowly cupular, inserted at base of gynostegium, fleshy, apex entire or shallowly undulate. Filaments connate; anthers very large, decurrent to base of column, apex acuminate; pollinia 2 per pollinarium, slender, falcate, pendulous. Stigma head scarcely umbonate. Follicles $8-14 \times 1-4 \mathrm{~cm}$, glabrous stout, cylindric-fusiform, slightly tapering to a blunt apex. Seeds ovate, ca. $5 \mathrm{~mm}$, margin membranous; coma $2-3 \mathrm{~cm}$.

Flowering Time: April to September.

\section{Daemia extensa (Jacq.) R. Br. (Fig 11)}

Twining, pubescent or tomentose undershrub; Leaves opposite, cordate. Flowers greenish- white, on slender pedicels, in axillary, recemose or corymbose cymes. Sepals connate in a 5-partite calyx, 5 glandular within; lobes acute. Petals 5, connate in a shortly funnel shaped corolla; lobes large, wide ovate, overlapping to the right; corona dauble; outer membranous, annular, 5-10 lobed or crenate; inner of 5 laterally compressed scales, spurred behind, vertically adnate to the anther, with long, free, subulate tips. Stamen 5, adnate to corolla-tube; filaments connate in a column; anther with membranous, inflexed tips; pollinarium solitary in each cell, oblong pollinium sac, subcompressed translator and distinct caudicle, pollinim pendulous and waxy. Carpels 2, distinct; stigma with depressed or concave top. Fruit of 2 thickish, rigid, acuminate, setoselyechinate follicles. Seeds comose.

Flowering Time: April to September.

\section{Hemidesmus indicus (L.) R. Br. (Fig 12)}

Twining shrubs; leaves opposite, glabrous. Flowers small in opposite, crowded, subsessile cymes, greenish-purple. Sepals 5, somewhat connate below, acuminate, each grandular within at the base. Petals 5, connate in a rotate corolla; lobes thick valvate; coronal scales 5 on the corolla throat, alternate with its lobe, short thick. Stamens 5; filament adnate to base of corolla tube, faintly connate at the base, free above; anthers with connate, inflexed, membranous tips; pollen masses cohering in pair in each cell, granular; appendages of corpuscles dilated or hood like. Carpel 2, many ovuled, styles distinct; stigma 5cornered, with flattened crown. Fruit of 2 long, slender, divaricate, terete, smooth follicles. Seeds comose.

Flowering Time: December to February.

\section{B. Micro-morphological analysis}

\section{B.1. Pollen- Pollinial structure of Asclepiadaceae}

B.1.1 Pollen or pollen tetrad structure of subfamily Periplocoideae

There are five pollen- carriers in each flower. The pollen carrier has an expanded distal erect translator, bent along with the stigma. Its proximal adhesive disc is directed towards the rim of the stigma. Both the translator and the adhesive disc are connected by the stipe. The translator, stipe and adhesive disc are non-cellular and they are the products of secretion. The translators are boat-shaped in Cryptolepis buchananii, and spoonshaped in Cryptostegia grandiflora. The shovel-shaped translator of both and Hemidesmus have a median partition wall, dividing it into two parts, each of which receives pollen tetrads in massulae of the nearest anther lobe. The translator, stipe and the adhesive disc are distinct in Hemidesmus and while the adhesive disc is not distinct and granular pollen in tetrads in $C$. buchananii. The pollen carriers are erect in the Periplocaceae.

\section{B. 1. 2. Pollinial structure of subfamily Asclepiadioideae} (Fig.13)
All the species examined under Asclepiadoideae posses' multicellular pollinia, non-cellular caudicles and corpuscules. The pollinial-apparatus are not morphologically identical. The characterstics of the pollinium such as orientation, length, shape, size and other aspects are presented in the Table 1 and 2. The pollinia in a flower are oriented in three different ways, these are A, Erectin which the vertical axes of the flower and pollinia are parallel and the free ends of the pollinia faces upwards. This is characterstic of Gymnema sylvestre, B, Horizontal in which the vertical axes of the flower and pollinia are at right angles to each other and the free ends of the pollinia are disposed towards the exterior of the gynostegium as in Tylophora indica and $\mathrm{C}$, Pendulous in which The orientation of the pollinia is as in the erect type but the free ends of the pollinia faces downwards as in the tribe Asclepiadoideae-Calotropis gigantean, Holostemma ada-kodien and Oxystelma esculentum etc.The corpuscles are dark brown in colour and harder in consistency than that of the pollinia and caudicles. The corpusculum is a stunted unit of two halves, placed exactly at the angular region of the pentangular stigma. The surface which is adjacent to the stigma is the dorsal surface and the side opposite to it, is the ventral surface. The median longitudinal portion of corpusculum is sutured at various levels along both faces. The suture is open throughout on the ventral surface as in Gymnema sylvestre, and in all species of the tribe Asclepiadeae. The sutures in all the species of Tylophora are open along both the faces up to the head. The corpuscules have a specific region to which the caudicle fits in. The split end of the corpusculum is usually associated with a membranous structure, except in Holostemma ada-kodien, the shape; size and orientation of caudicles are found to be significant in taxonomy. The caudicle in Oxystelma esculentum is very short; the caudicle of Tylophora indica is cylindrical and ornamented on the surface. The caudicle may be attached to the terminal or sub terminal region of the pollinium. Three types of caudicles are recognized; club-shaped, triangular and cylindrical. In Asclepias, the caudicle runs horizontally and then bends downwards at right angles and joins the pollinium. In Holostemma ada-kodien, it is obliquely oriented downwards and attaches with the pollinium at the other end and in the middle, a horn-like structure faces upwards. The caudicle in the other taxa faces either obliquely upwards or downwards. The former type is found in species with erect pollinia, and the latter type in species with pendulous pollinia. In few others, the pollinia are horizontal and the caudicles run at a right angle to the long axis of the flower. In most of the taxa, the caudicle bears a membranous undulated structure. Pollinium orientation has been used as a diagnostic character for suprageneric taxa recognized within Asclepiadaceae (Swarupanandan, 1996; Civeyrel et al., 1998). Often three tribes have been recognized defined by erect, horizontal, and pendulous pollinia. Swarupanandan et al., (1996) reevalueted this partitioning of pollinium orientation and presentedrefined categories, emphasizing the importance of the orientation anther locule and the position of the attachment of the translator; Thus, the horizontally oriented pollinia of Gonolobeae have morphologically equivalent translator attachments as the pendulous pollinia of Asclepiadaceae. Swarupanandan et al., (1996) advocated using multiple criteria to evaluate whether the translator is attached to the part of the pollinium positioned apically or basally of the locule. I have adopted these criteria for analyzing the evolution of pollinia orientation, bearing in mind the exceptions noted by Endress and Bruyns (2000). Also, I have treated the very different adhesive attachment of pollinia to translators in Periplocoideae as nonhomologous. As with pollinia number per stamen, the evolution of the position of translator attachment is reconstructed to have been conservative. Assuming that pollinia 
originated once in the common ancestor of Secamonoideae and Asclepiadoideae the ancestral point of attachment is unambiguously reconstructed to be basal. A single change from basal to apical translator attachment is inferred in the ancestor of Asclepiadaceae; no reveals are apparent among the representatives of this large tribe. Thus, no homoplasy is evident in the single most parsimonious reconstruction. It should be noted, however, that the sparse sampling in the present study may obscure homoplasious convergence to apical attachment among clades coded as uniformly basal reversal to basal attachment in Ascleoiadaceae (Endress and Bruyns, 2000). A rigorous basis for assessing the homology of ambiguous cases would be a comperative ontogenetic study of polinaria (Safwat, 1962, Kunze, 1993).

\section{B.2. Corolline corona}

Corolline coronas are defined by structural and topological criteria: (1) they are composed of five distinct segments; and (2) they are positioned on the corolla, alinged with the sinuses of the limb (Good, 1956; Kunze, 1990; Nilson et al., 1993). My analysis of coralline coronas explicitly excludes annular coronas (Liede and kunze, 1993), which are conspicuous in a number of Gonolobinae and Ceropegieae, but do not appear to be homologous (Endress and Bruyns, 2000). Corolline coronas have been considered to be prevalent in Periplocoideae, but very uncommon in Asclepiadoideae (kunze, 1990; Nilsson et al., 1993). They have been reported from Secamonoideae, but their distribution in this subfamily has been little discussed (Safwat, 1962; kunze, 1990). Corolline coronas are also found widely among non-asclepiad Apocynaceae (kunze, 1990; Endress and Bruyns, 2000). The taxonomic distribution of coralline coronas has suggested that they are ancestral in Asclepiadaceae (Good, 1956; Kunze, 1990; Kunze, 1993). Parsimony reconstruction of evolutionary history of coralline coronas is assuming their uniform presence in Periplocoideae. The common ancestor of Asclepiadaceae is inferred to possess a coralline corona, which is a retained plesiomorphy present in related Apocynaceae (ef. Good, 1956; kunze, 1990; Kunze, 1993). This ancestral coralline corona is retained in Periplocoideae, and no losses of coralline coronas are inferred among the sampled taxa. The presence of a coralline corona in the ancestors of Asclepiadacea, Periplocoideae, Secamonoideae, and Asclepiadoideae +Secamonoideae is equivocal in each case. This greater degree of uncertainty is due entirely to variation in the presence of coralline coronas in periplocoideae. As a result, it is equally parsimonious to infer that those Periplocoideae with coralline coronas have retained them from non-asclepiad relatives, or that they have evolved convergently.

\section{B.3. Gynostegial coronas}

Gynostegial coronas exhibit a far greater range of diversity of form than corolline coronas; My use of "gynostegial" corona follows Kunze (1993) and is largely equivalent to the "true" corona of Endress and Bruyns (2000) and the "staminal" corona of Good (1956), and Kunze (1990). I coded gynostegial coronas as exhibiting two basic forms: separate staminal segrnents and united staminal and interstaminal segments. Although Kunze (1993) distinguished staminal and interstaminal corona segments as fundamentally distinct types (i.e. as different from one another as each is from corolline coronas). There are three reasons to prefer treating these types as homologous, differing simply through elaboration in adjacent sectors of the flower, first; interstaminal segments are almost always united with staminal segments. Second; there are many taxa (e.g. Cynanchum L.: Endress and Bruyns. 2000) in which the corona is tubular with little elaboration in the staminal or interstaminal sectors, third coronas with interstaminal segments; but lacking staminal segments. As with the analysis of coralline coronas, reconstruction of the evolutionary history of gynostegial coronas depends on the assessment of the corona type of Periplocoideae. I begin by assuming that all coronas of Periplocoideae are coralline, and that gynostegial coronas are absent [Table 3]. Under this scenerio, the common ancestor of Asclepiadaceae is inferred unambiguously to lack a gynostegial corona. The time of origin of the gynostegial corona, however, is ambiguous. Asclepiadoideae are inferred to possess a gynostegial corona ancestrally; but the presence of this corona type in the common ancestor of Asclepiadoideae and Secamonoideae is equivocal. It is equally parsimonious to infer that this ancestor lacked a gynostegial corona, possessed a corona of distinct staminal segments. Or possessed a corona of united staminal and interstaminal segments. This ambiguity arises because the lineages descending from this ancestor are inferred to have evolved different gynostegial corona types: the ancestral corona type of Asclepiadoideae is composed of staminal and interstarninal segments, but that of Secamonoideae is composed only of staminal segments ; Any step in matrix that weights the gain of gynostegial coronas greater (no matter how slightly) than transitions between distinct staminal coronas and united staminal and interstaminal coronas would make the inference of a lack of gynostegial corona in the common ancestor of Asclepiadoideae and Secamonoideae less parsimonious than the presence of either type of gynostegial corona. Thus, weighting the origin of 'the gynostegial corona greater than transitions between free starninal and united staminal and interstaminal forms supports the single origin of gynostegial coronas in the common ancestor of Asclepiadoideae and Secamonoideae, although the form of the corona is equivocal; Coronas of united staminal and interstaminal segments are restricted to Asclepiadoideae, and are inferred to be the ancestral corona form in subfamily. Although the reduction to two anther locules has long been noted as a synapomorphy of this subfamily, the importance of the form of the gynostegial corona has been less appreciated. Within Asclepiadoideae, there is a low level of homoplasy in gynostegial coronas, among sampled taxa. Most importantly, the tribe Marsdenieae is characterized by a corona composed of distinct staminal segments. Although this corona type is shared with Secamonoideae, the most parsimonious inference is that it is convergent in these clades, rather than phylogenetically homologous. Thus, a gynostegial corona of distinct stamina segments appears as a synapomorphy of Marsdenieae. It is noteworthy that Swarupanandan et al., (1996) could find no morphological synapomorphy for Marsdenieae which they submerged under Stapelieae (Ceropegieae). Convergence of staminal coronas in Marsdenieae and Secamonoideae also refuges Kunze's (1995) hypothesis that staminal coronas are homologous and plesiomorphie in these groups. Recoding some Periplocoideae as possessing a gynostegial corona results in ambiguity concerning the ancestral absence of a gynostegial corona in Asclepiadaceae, and introduces additional homoplasy among Periplocoideae. The presence of gynostegial coronas in some Periplocoideae permits with equal parsimony the common ancestor of Asclepiadaceae to either lack a gynostegial corona or possess one of distinct staminal segments; a corora of united staminal and interstaminal segments, however, is less parsimonious. Similarly, it is equally parsimonious to infer that the ancestor of Periplocoideae lacked a gynostegial corona or possessed one of distinct staminal segments. If such a corona was absent in the ancestor of Periplocoideae, and then independent derivation is implied within subfamily. If a gynostegial corona was ancestral in Periplocoideae, then one or more losses must have occurred. Because taxa bearing ambiguous corona types may 
be oversampled in this study, further sampling of Periplocoideae may support the convergent evolution of gynostegial coronas in this subfamily, if they indeed should be coded as gynostegial (Kunze, 1990; Nilsson et al., 1993; Endrees and Bruyns, 2000).

\section{Discussions}

The pollinia show a great variation in form, varying from oval to globular. The size, shape, colour, pollinia attachment, orientation of pollinia, position of pollinia within anther etc are valuable characters for the analysis of diversification of pollinia of the Asclepiadaceae. The pollinial sacs are thin and flat. Their size, shape, colour, orientation of pollinia, position of caudicle or translator attachment to the corpusculum, are differ according to from genera. From the Table 1 and Graph 1, it was found that within the nine members, the largest pollinial sac found in Calotropis gigantea and amallest in Gymnema. The shape of pollinial sacs more or less oval but globular shape is found in Tylophora. The genus Gymnema possesses intermediate shape neither oval nor globular. The colour is also differing in different genera. Pollinium orientation has been used as a diagnostic character for systematic studies in the family Asclepiadaceae. The classic division of Asclepiadoideae into three tribes which is based on the orientation of the pollinium relative to the translator. Three tribes have been recognized by erect, horizontal, and pendulous pollinia. In Calotropis and
Daemia, the pollinia are pendulously orientated within the anther locule and horizontal orientation of pollinia is found in Dregea, Oxystelma and Gymnema. But the orientation of pollinia of Tylophora is questioned due to pollinia are slightly erect, that is why this type of pollinia recognized as erect pollinia. Position of attachment of translator or caudicle to the pollinia is also important diagnostic feature to evaluate the morphological diversification of pollinia of different genera of Asclepiadaceae. The translator attachment is either apical or basal. In Periplocoideae the translator attachment is absent because the mechanism in this subfamily is via adhesion, following flower maturation. This condition is differing substantially from Secamonodeae and Asclepiadoideae in which the attachment of pollinia to the translator occurs much earlier in development by different mechanism (Brown 1811; Swarupnandan et al., 1996). From the Table 3 it was found that the basal attachment is found in Calotropis, Dregea and Oxystelma and apical attachment of pollinia found in Daemia, Tylophora and Gymnema. The length and breadth of pollinium sac, translator and corpusculum is also differing from species to species. All Micro-morphological characters are indicated by 0 , 1 and 2 [Table 3] for phylogenetic analysis of 12 selected plant species of the family Asclepiadaceae. Then all micromorphological Characters are coded by 0,1 and 2 [Table 4] for cladistic analysis of 12 selected plant species of the family Asclepiadacae based on Table 3 .

Table 1. Size of Pollinarium

\begin{tabular}{lcccc}
\hline \multicolumn{1}{c}{ Name of plant } & Shape of pollinial sac & Colors of pollinia & Orientation of pollinia & $\begin{array}{c}\text { Translator attachment } \\
\text { to the pollinia }\end{array}$ \\
\hline Calotropis gigantea & Oval & Canary yellow & Pendulous & Basal \\
Calotropis procera & Oval & Sulphur yellow & Pendulous & Basal \\
Daemia extensa & Oval & Canary yellow & Pendulous & Apical \\
Oxystelma esculentum & Oval & Lemon yellow & Horizontal & Basal \\
Dregea volubilis & Oval & Sulphur yellow & Horizontal & Basal \\
Tylophora indica & Globular & Canary yellow & Erect & Apical \\
Tylophora tenuis & Globular & Canary yellow & Erect & Apical \\
Gymnema sylvestre & Intermediate & Mimosa Yellow & Horizontal & Apical \\
Holostemma ada-kodien & Oval & Canary yellow & Pendulous & Basal \\
\hline
\end{tabular}

Table 2. Shape, Colour, and orientation and translator attachment of pollinial sacs of nine members of Asclepiadaceae

\begin{tabular}{|c|c|c|c|c|c|c|}
\hline Name of plant & $\begin{array}{l}\text { Mean Length of } \\
\text { pollinium sac }(\mu \mathrm{m})\end{array}$ & $\begin{array}{l}\text { Mean Breadth of } \\
\text { pollinium sac }(\mu \mathrm{m})\end{array}$ & $\begin{array}{l}\text { Mean Length of } \\
\text { translator }(\mu \mathrm{m})\end{array}$ & $\begin{array}{c}\text { Mean Breadth of } \\
\text { translator }(\mu \mathrm{m})\end{array}$ & $\begin{array}{l}\text { Mean Length of } \\
\text { corpusculum }(\mu \mathrm{m})\end{array}$ & $\begin{array}{c}\text { Mean Breadth of } \\
\text { corpusculum }(\mu \mathrm{m})\end{array}$ \\
\hline Calotropis gigantea & 950.57 & 379.82 & 130.28 & 43.29 & 378.14 & 150.45 \\
\hline Calotropis procera & 940.39 & 394.71 & 131.32 & 45.25 & 370.30 & 130.47 \\
\hline Daemia extensa & 451.43 & 188.64 & 30.17 & 14.83 & 138.42 & 94.59 \\
\hline Oxystelma esculentum & 874.00 & 209.95 & 125.32 & 34.82 & 219.11 & 107.13 \\
\hline Holostemma ada-kodien & 390.25 & 112.62 & 90.47 & 26.07 & 365.68 & 80.70 \\
\hline Dregea volubilis & 361.21 & 116.08 & 104.39 & 21.51 & 251.2 & 82.04 \\
\hline Tylophora indica & 190.33 & 140.86 & 81.35 & 25.63 & 90.9 & 60.67 \\
\hline Tylophora tenuis & 181.26 & 141.30 & 82.01 & 28.70 & 95.57 & 62.23 \\
\hline Gymnema sylvestre & 105.27 & 55.47 & 70.68 & 41.66 & 35.15 & 21.04 \\
\hline
\end{tabular}

Table 3. Micro-morphological characters indicated by 0,1 and 2 for phylogenetic analysis of 12 selected plant species of the family Asclepiadaceae.

\begin{tabular}{|c|c|c|c|c|}
\hline \multirow{2}{*}{ S.No. } & \multirow{2}{*}{ Character } & \multicolumn{3}{|c|}{ Characteristics symbol } \\
\hline & & 0 & 1 & 2 \\
\hline 1 & Habit & Perennial climber & Erect herb/shrub & \\
\hline 2 & Tuber & Absent & Present & \\
\hline 3 & Stem & Erect & Herbacious/climbing & \\
\hline 4 & Stem bark & Bark brownish and glabrous, hairy & Bark grayish, glossy and flaky & \\
\hline 5 & Inflorescence & 1 to 10 flowers and recemose or umbel like & Few flowered and panicle like & \\
\hline 6 & Calyx & Glabrous & Hairy & \\
\hline 7 & Corolla & Campanulate and large & Rotate or reflexed and small & \\
\hline 8 & Corolla covering & Glabrous & Hairy & \\
\hline 9 & Aestivation of corolla & Imbricate or twisted & valvate & \\
\hline 10 & Corolline corona & Absent & Present & \\
\hline 11 & Gynostegial or stamina corona & Absent & Present & \\
\hline 12 & Nature of gynostegial corona & Absent & Free staminal segment & United staminal segment \\
\hline 13 & Gynostegium & Absent & Present & \\
\hline 14 & Manner of attachment of pollinator & Viscidium & Corpusculum & \\
\hline 15 & Pollinarium & Absent & Present & \\
\hline 16 & Attachment of translator to Pollinium & Absent & Apical & Basal \\
\hline 17 & Position of pollinarium & Absent & Horizontal or erect & Pendulous \\
\hline 18 & Size of Pollinium & Absent & Oblong & Globose \\
\hline
\end{tabular}




\begin{tabular}{|c|c|c|c|c|}
\hline 19 & Colour of Pollinarium & Absent & lemon yellow & Sulphur yellow \\
\hline 20 & Length of Pollinium sac $(\mu \mathrm{m})$ & Absent & $0-500$ & $501-1000$ \\
\hline 21 & Breadth of Pollinium sac ( $\mu \mathrm{m})$ & Absent & $0-200$ & $201-400$ \\
\hline 22 & Length of Caudicle $(\mu \mathrm{m})$ & Absent & $0-100$ & $101-200$ \\
\hline 23 & Breadth of Caudicle $(\mu \mathrm{m})$ & Absent & $0-50$ & $51-100$ \\
\hline 24 & Length of Corpusculum $(\mu \mathrm{m})$ & Absent & $0-200$ & $201-400$ \\
\hline 25 & Breadth of Corpusculum ( $\mu \mathrm{m})$ & Absent & $0-75$ & $76-150$ \\
\hline 26 & Shape of follicle fruit & Cylindrical & Broadly keel shaped & \\
\hline
\end{tabular}

Table 4. Character coding of 26 micro-morphological characters for cladistic analysis of 12 selected plant species of the family Asclepiadacae based on Table 3.

\begin{tabular}{|c|c|c|c|c|c|c|c|c|c|c|c|c|c|c|c|c|c|c|c|c|c|c|c|c|c|c|}
\hline Charactere & & 2 & 3 & & & & & & & 1 & 1 & 1 & 1 & 1 & 1 & 1 & 1 & 1 & 1 & 2 & 2 & 2 & 2 & 2 & 2 & 2 \\
\hline Characters & 1 & 2 & 3 & 4 & 5 & 6 & 7 & 8 & 9 & 0 & 1 & 2 & 3 & 4 & 5 & 6 & 7 & 8 & 9 & 0 & 1 & 2 & 3 & 4 & 5 & 6 \\
\hline Cryptostegia grandiflor & 1 & 0 & 0 & 0 & 0 & 1 & 0 & 0 & 0 & 1 & 0 & 0 & 0 & 0 & 0 & 0 & 0 & 0 & 0 & 0 & 0 & 0 & 0 & 0 & 0 & 0 \\
\hline Cryptolepis buchanani & 0 & 0 & 1 & 1 & 1 & 0 & 0 & 0 & 0 & 0 & 0 & 0 & 0 & 0 & 0 & 0 & 0 & 0 & 0 & 0 & 0 & 0 & 0 & 0 & 0 & 0 \\
\hline Hemidesmus indicus & 0 & 1 & 1 & 1 & 0 & 1 & 1 & 0 & 1 & 1 & 1 & 0 & 0 & 0 & 0 & 0 & 0 & 0 & 0 & 0 & 0 & 0 & 0 & 0 & 0 & 0 \\
\hline Calotropis gigentea & 1 & 0 & 0 & 0 & 0 & 1 & 0 & 1 & 1 & 0 & 1 & 1 & 1 & 1 & 1 & 1 & 2 & 2 & 1 & 2 & 2 & 2 & 1 & 2 & 2 & 1 \\
\hline Calotropis procera & 1 & 0 & 0 & 0 & 0 & 1 & 0 & 0 & 1 & 0 & 1 & 1 & 1 & 1 & 1 & 1 & 2 & 2 & 1 & 2 & 2 & 2 & 1 & 2 & 2 & 1 \\
\hline Daemia extensa & 0 & 0 & 1 & 1 & 0 & 1 & 0 & 1 & 0 & 0 & 1 & 1 & 1 & 1 & 1 & 1 & 2 & 1 & 1 & 1 & 1 & 2 & 2 & 1 & 1 & 1 \\
\hline Dregia voluvilis & 1 & 0 & 0 & 0 & 0 & 0 & 0 & 0 & 0 & 0 & 1 & 2 & 1 & 1 & 1 & 2 & 1 & 1 & 2 & 1 & 1 & 2 & 1 & 2 & 2 & 1 \\
\hline Oxystelma esculentum & 0 & 0 & 1 & 1 & 1 & 1 & 1 & 0 & 0 & 0 & 1 & 2 & 1 & 1 & 1 & 1 & 2 & 2 & 1 & 2 & 2 & 1 & 2 & 2 & 2 & 1 \\
\hline Gymnema sylvestris & 0 & 0 & 1 & 1 & 0 & 1 & 0 & 0 & 0 & 0 & 1 & 2 & 1 & 1 & 1 & 2 & 1 & 1 & 2 & 1 & 1 & 1 & 1 & 1 & 1 & 0 \\
\hline Tylophora indica & 0 & 0 & 1 & 1 & 0 & 1 & 0 & 0 & 0 & 0 & 1 & 2 & 1 & 1 & 1 & 1 & 1 & 1 & 1 & 1 & 1 & 1 & 1 & 1 & 1 & 0 \\
\hline Tylophora tenuis & 0 & 0 & 1 & 1 & 0 & 0 & 0 & 0 & 0 & 0 & 1 & 2 & 1 & 1 & 1 & 1 & 1 & 1 & 1 & 1 & 1 & 1 & 1 & 1 & 1 & 0 \\
\hline Holostomaada-kodein & 0 & 0 & 1 & 1 & 1 & 1 & 0 & 0 & 0 & 0 & 1 & 2 & 1 & 1 & 1 & 1 & 2 & 1 & 1 & 1 & 1 & 1 & 1 & 2 & 2 & 1 \\
\hline
\end{tabular}

Table 5. Data matrix for constructions of Dendogram (UPGMA) of selected 12 plant Taxa under the family Asclepiadaceae

\begin{tabular}{|c|c|c|c|c|c|c|c|c|c|c|c|c|}
\hline Plant taxa & C.grandiflora & C.buchanani & H.indicus & C.gigentea & C.procera & D.extensa & D.volubilis & O.esculentum & G.sylvestre & T.indica & T.tenuis & H.ada-kodien \\
\hline Cryptostegia grandiflora & 1 & & & & & & & & & & & \\
\hline Cryptolepis buchanani & 0.76 & 1 & & & & & & & & & & \\
\hline Hemidesmus indicus & 0.73 & 0.69 & 1 & & & & & & & & & \\
\hline Calotropis gigentea & 0.26 & 0.11 & 0.15 & 1 & & & & & & & & \\
\hline Calotropis procera & 0.03 & 0.15 & 0.19 & 0.96 & 1 & & & & & & & \\
\hline Daemia extensa & 0.19 & 0.26 & 0.23 & 0.61 & 0.57 & 1 & & & & & & \\
\hline Dregea volubilis & 0.03 & 0.23 & 0.11 & 0.61 & 0.65 & 0.61 & 1 & & & & & \\
\hline Oxystelma esculentum & 0.15 & 0.03 & 0.26 & 0.61 & 0.65 & 0.61 & 0.46 & 1 & & & & \\
\hline Gymnema sylvestris & 0.26 & 0.34 & 0.30 & 0.38 & 0.42 & 0.69 & 0.69 & 0.53 & 1 & & & \\
\hline Tylophora indica & 0.26 & 0.34 & 0.30 & 0.46 & 0.50 & 0.76 & 0.61 & 0.61 & 0.92 & 1 & & \\
\hline Tylophora tenuis & 0.23 & 0.38 & 0.26 & 0.42 & 0.46 & 0.73 & 0.65 & 0.57 & 0.88 & 0.96 & 1 & \\
\hline Holostemma ada-kodien & 0.19 & 0.34 & 0.23 & 0.57 & 0.61 & 0.73 & 0.65 & 0.80 & 0.73 & 0.80 & 0.76 & 1 \\
\hline
\end{tabular}
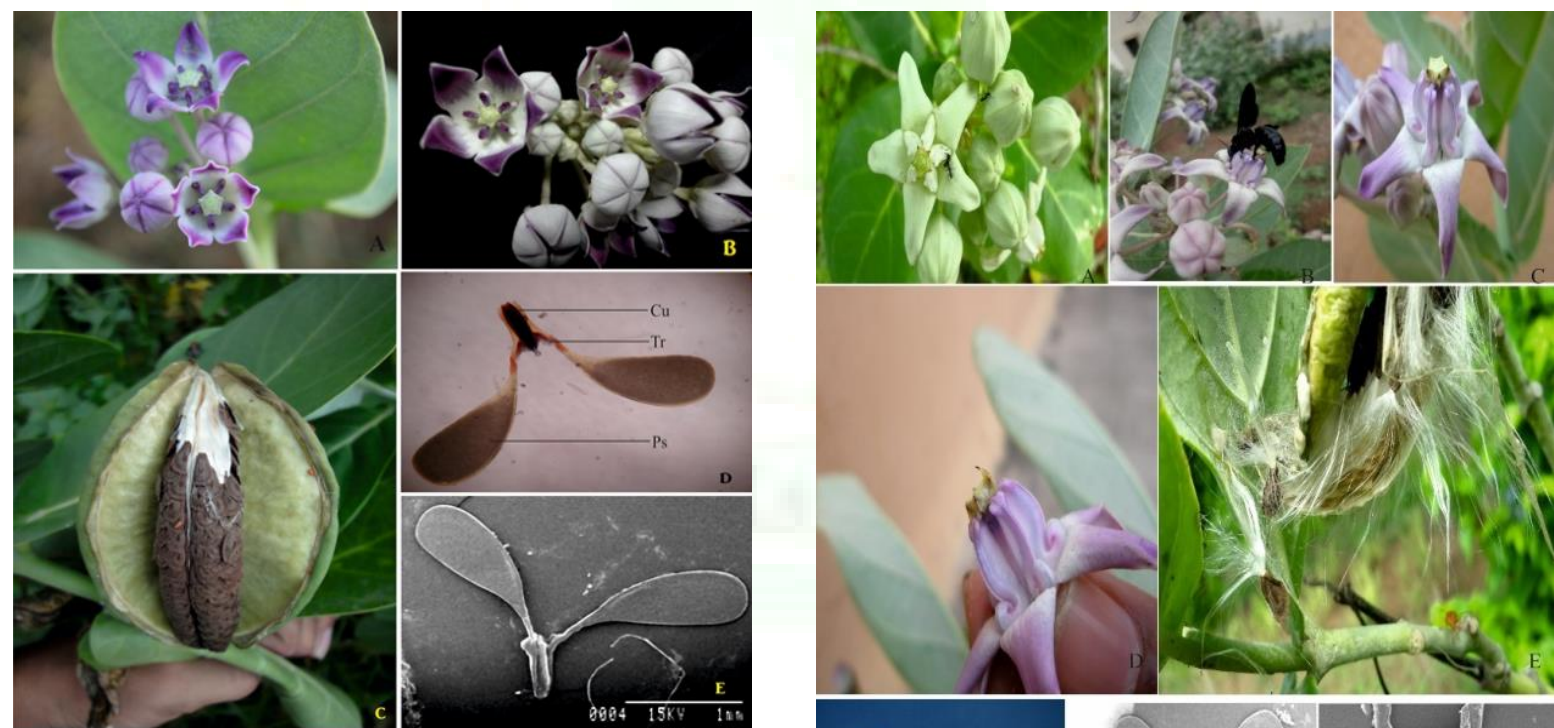
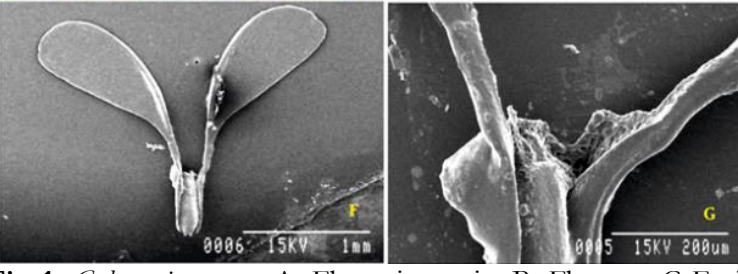

Fig 1: Calotropis procera A. Flowering twig, B. Flowers, C Fruit Showing Seeds, D. LM image of Pollinarium, E-F. SEM image of Pollinarium. G. SEM image of Corpusculum

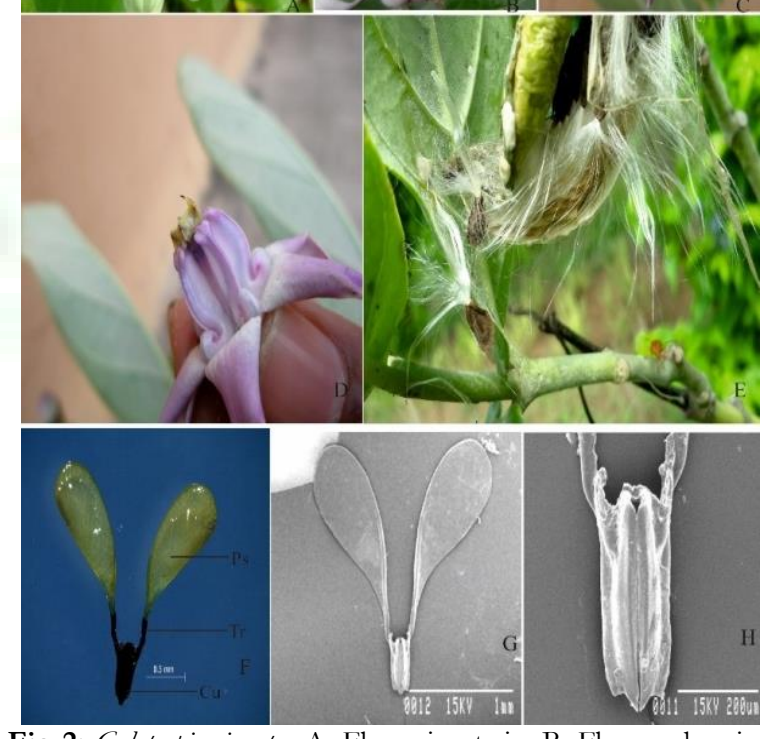

Fig 2: Calotropis gigantea A. Flowering twig, B. Flower showing pollination, C. An individual flower, D. Flower showing pollinarium E. comose seeds, F. LM of pollinarium, G. SEM image of Pollinarium, H. SEM image of corpusculum 


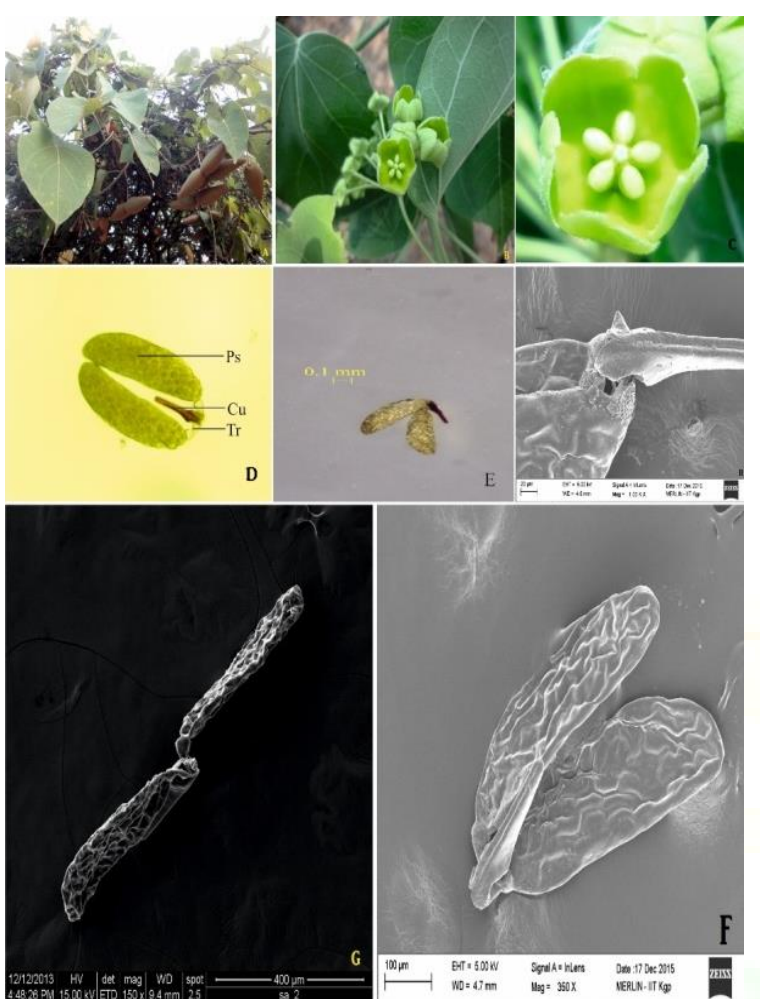

Fig 3: Dregea volubilis A. Twig with fruits, B. Flowering twig. C. Single Flower, D\&F. LM image of pollinarium F\&G. SEM image of pollinarium, H. SEM image of corpusculum.

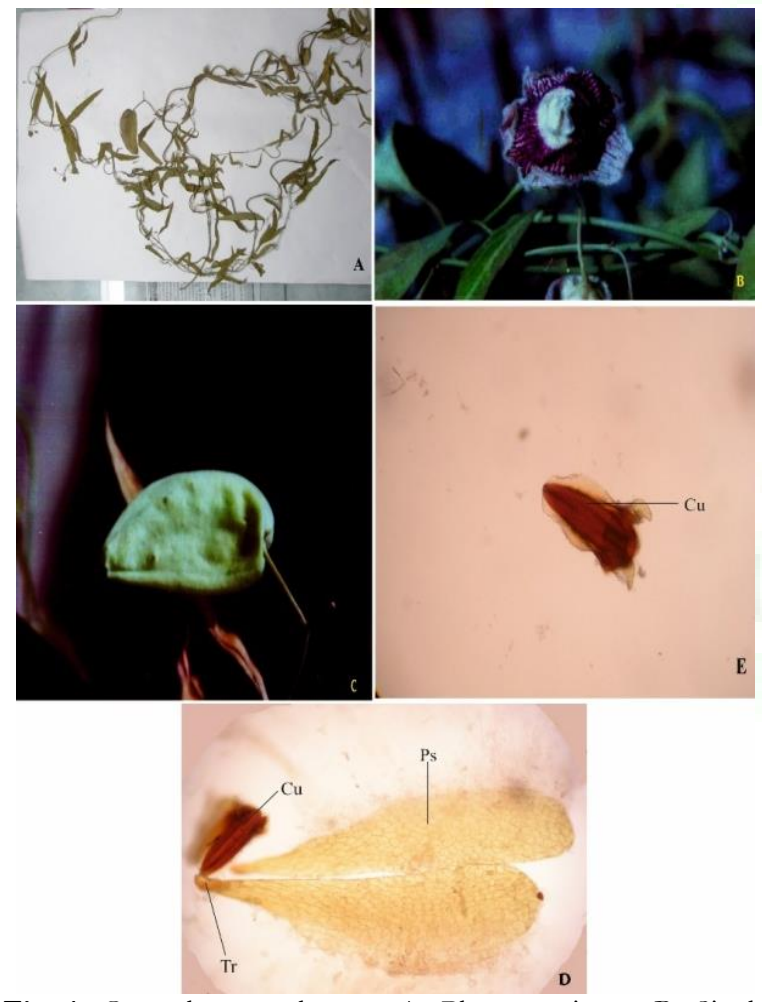

Fig 4: Oxystelma esculentum A. Plant specimen, B. Single flower, C. Fruit, D. LM image of pollinarium, E. LM image of corpusculum

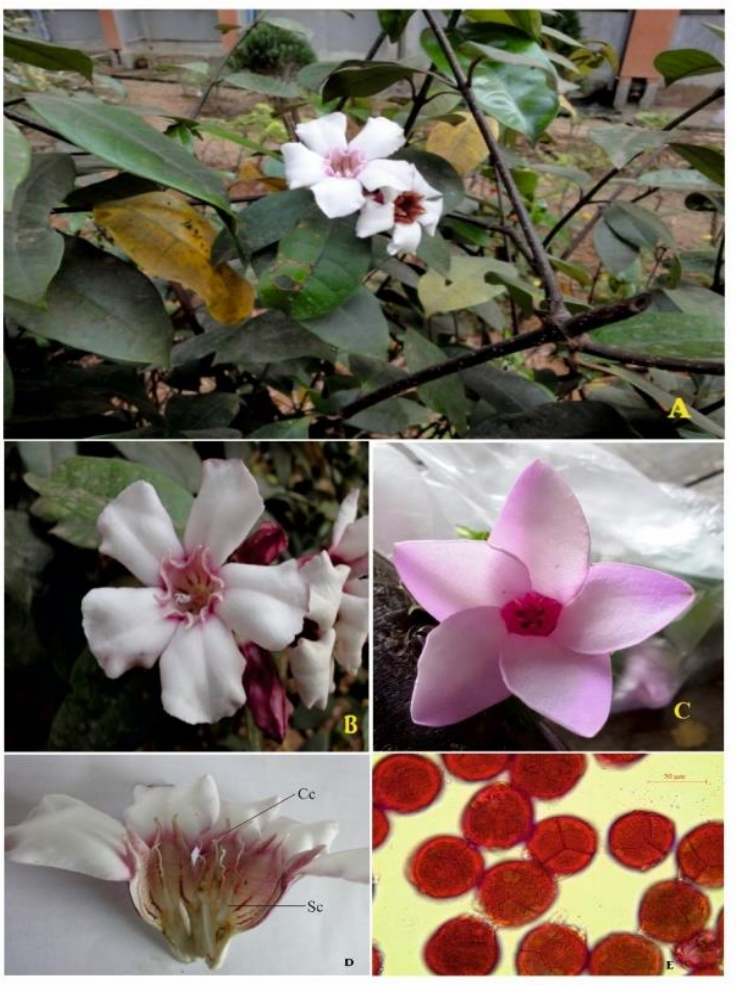

Fig 5: Cryptostegia grandiflora A. Flowering twig, B \& C. single flower, D. LS of Single flower, E. LM image of pollen grains

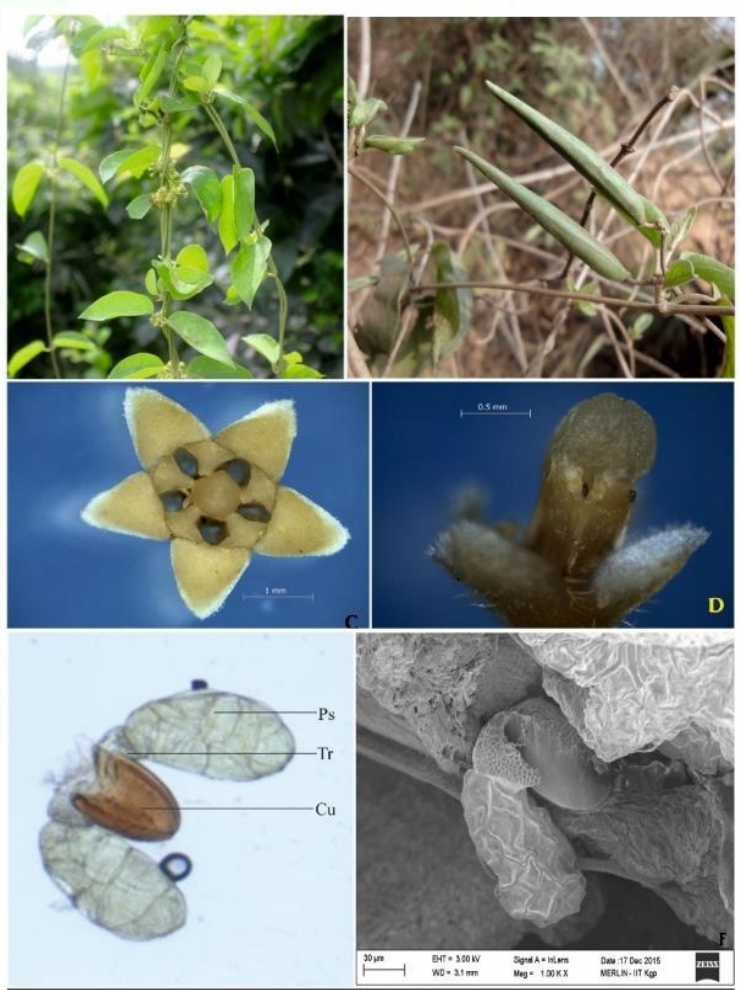

Fig 6: Gymnema sylvestre. A. Flowering twig, B. Twig bearing fruit, C. LM image of flower. D Gynostegium of flower, E. LM image of pollinarium, F. SEM image of pollinarium 


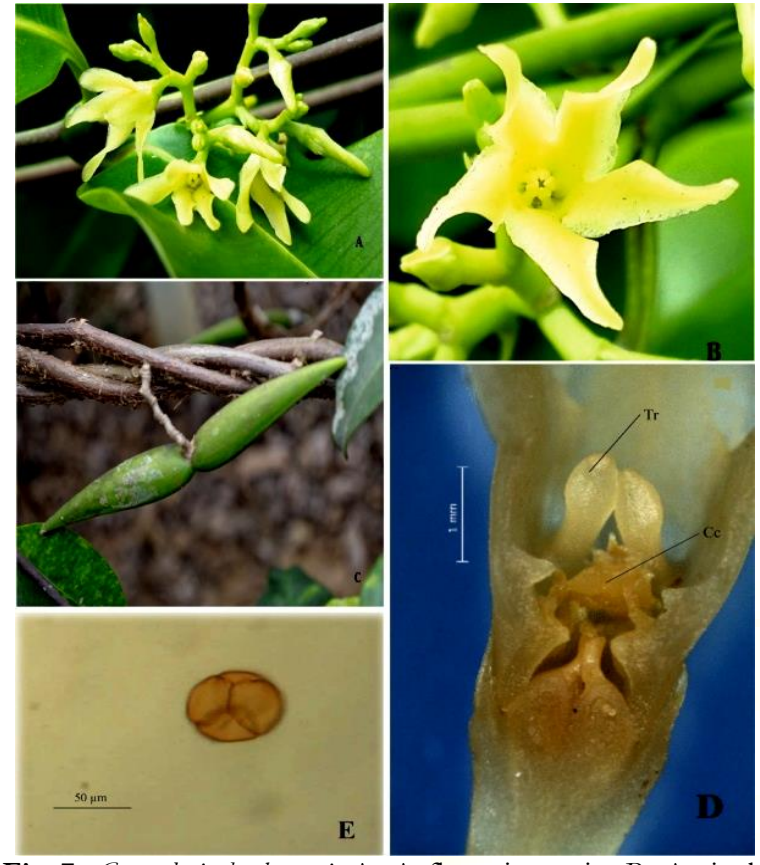

Fig 7: Cryptolepis buchanani, A. A flowering twig, B. A single flower, C. Fruit, LM image of ls of flower, E. LM image of pollen tetrad

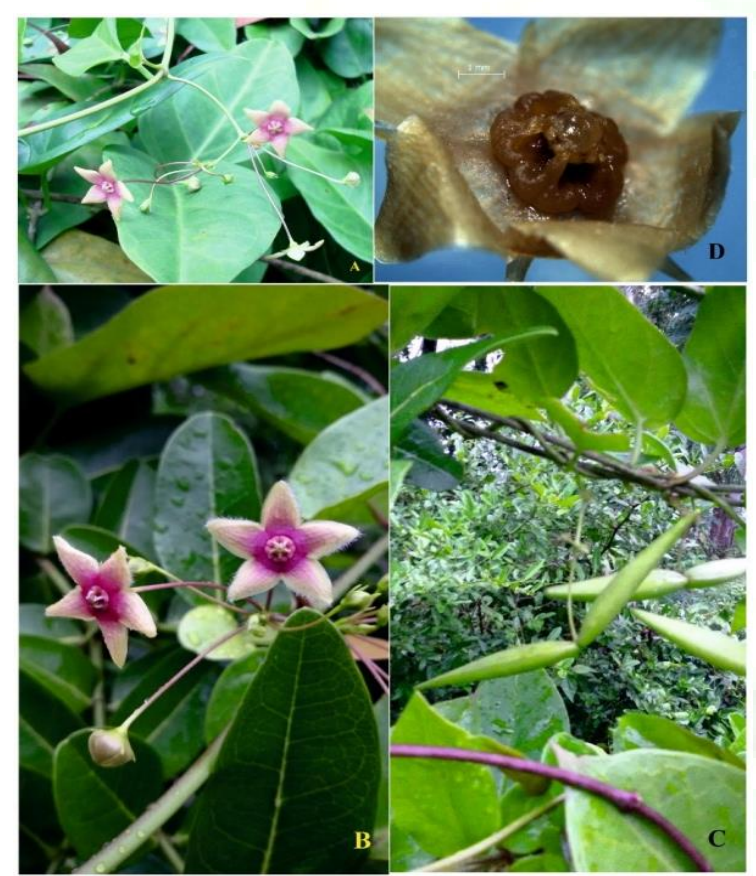

Fig 8.A: Tylophora indica A. Flowering twig, B. Single flower, C. Twig bearing fruit, D. LM image of flower

The investigated twelve (12) species belonging to the family Asclepiadaceae were found to form cluster in the dendogram [Fig- 14] which is formed depending upon the micromorphological characters of pollinia i.e. size, shape, colour, orientation of pollinia etc. The dendogram constructed through the similarity matrix [Table 5] which is based on Table 3 and 4 using UPGMA (Unweighted Pair Groups Method with Arithmetic averages) which divided the investigated species into four clusters. The coefficient value of these clusters ranges from $0.25 \%$ to $0.96 \%$ [Fig. 14 ].
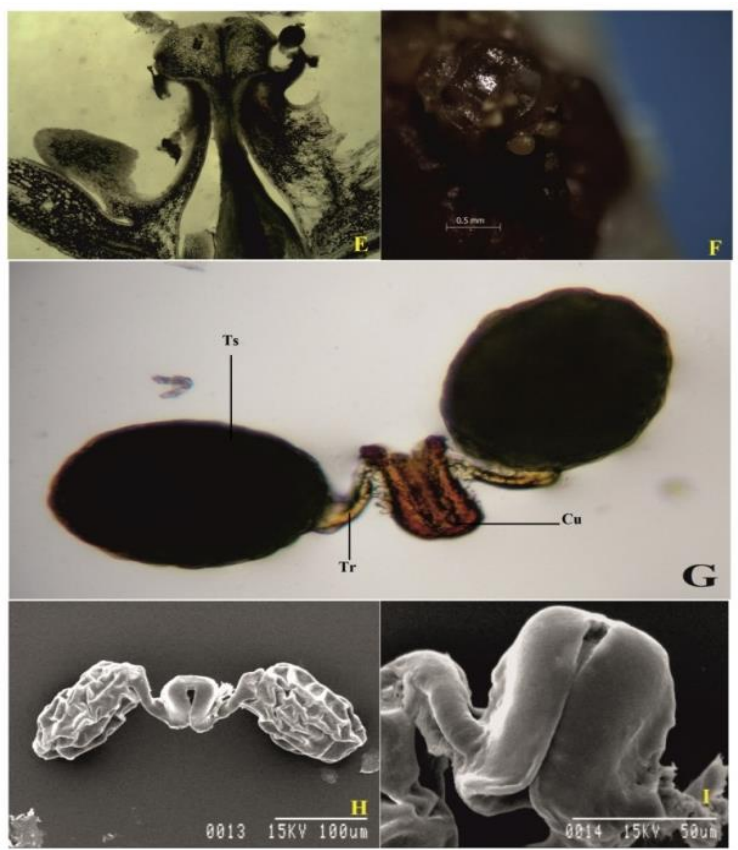

Fig 8.B: Tylophora indica E. LM image of ls of flower, F. LM image of gynostegium, G. LM image of pollinarium, H \& I. SEM image of pollinarium and corpusculum

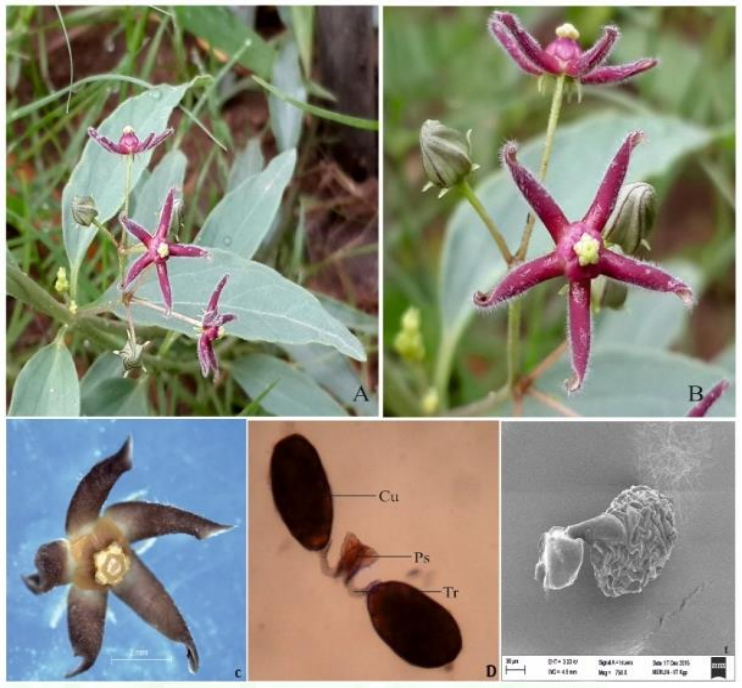

Fig 9: Tylophora tenuis A. Flowering twig, B. Flower, C. LM image of Flower, D. LM image of Pollinarium, E. SEM image of pollinarium

\section{Cluster-I}

The cluster-I is consisting of three species in which the pollinarium structure is absent There are five pollen- carriers in each flower. The pollen carrier has an expanded distal erect translator, bent along with the stigma. Its proximal adhesive disc is directed towards the rim of the stigma. Both the translator and the adhesive disc are connected by the stipe. The translator, stipe and adhesive disc are non-cellular and they are the products of secretion. The translators are boat-shaped in Cryptolepis buchananii, and spoon- shaped in Cryptostegia grandiflora. The shovel-shaped translator of both and Hemidesmus have a median partition wall, dividing it into two parts, each of which receives pollen tetrads in massulae of the nearest anther lobe. The translator, stipe and the adhesive disc are distinct in Hemidesmus and while the adhesive disc is not distinct and granular pollen in tetrads in C. buchananii. The pollen carriers are erect in the Periplocaceae. 

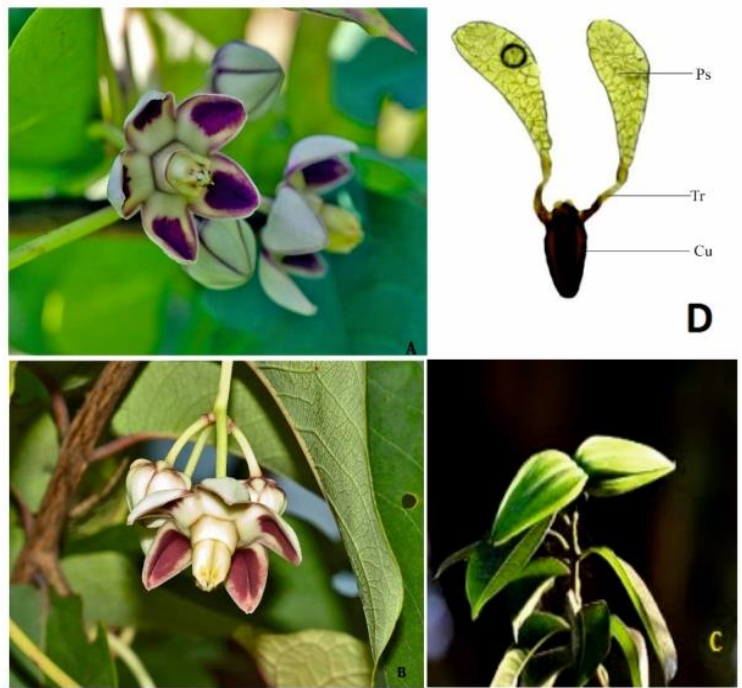

Fig 10: Holostemma ada-kodien A. Flowering twig, B. Flower, C. Fruit, D. LM image of pollinarium

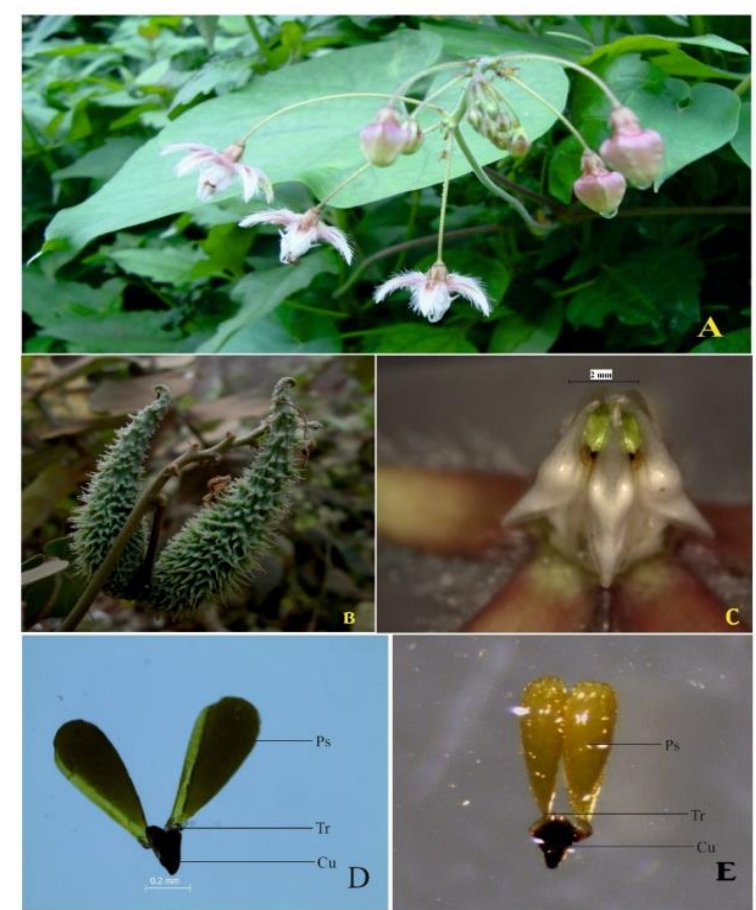

Fig 11: Daemia extensa A. Flowering twig, B. Fruit, C. LM image of flower, D \& E. LM image of pollinarium

\section{Cluster-II}

This cluster is consisting of four species in which all the species characterized by small flower with small pollinarium. In Gymnema sylvestre the pollinium $\mathrm{sac}$ is globular shapewith intermediate size and the manner of translator attachment to the pollinia is apical which is also found in two species of Tylophora. The orientation and position of pollinium sac is pendulous in Daemia extensa which is differ from other thre species. In the pollinarium structure of Tylophora indica small hair is present in outer surface of corpusculum but smooth surface of corpusculum is present in Tylophora tenuis.

\section{Cluster-III}

This cluster is consisting of two species in which the moderate size of pollinarium is found. The size of Holostemma ada-kodien is relatively shorter than Oxystelma esculentum.

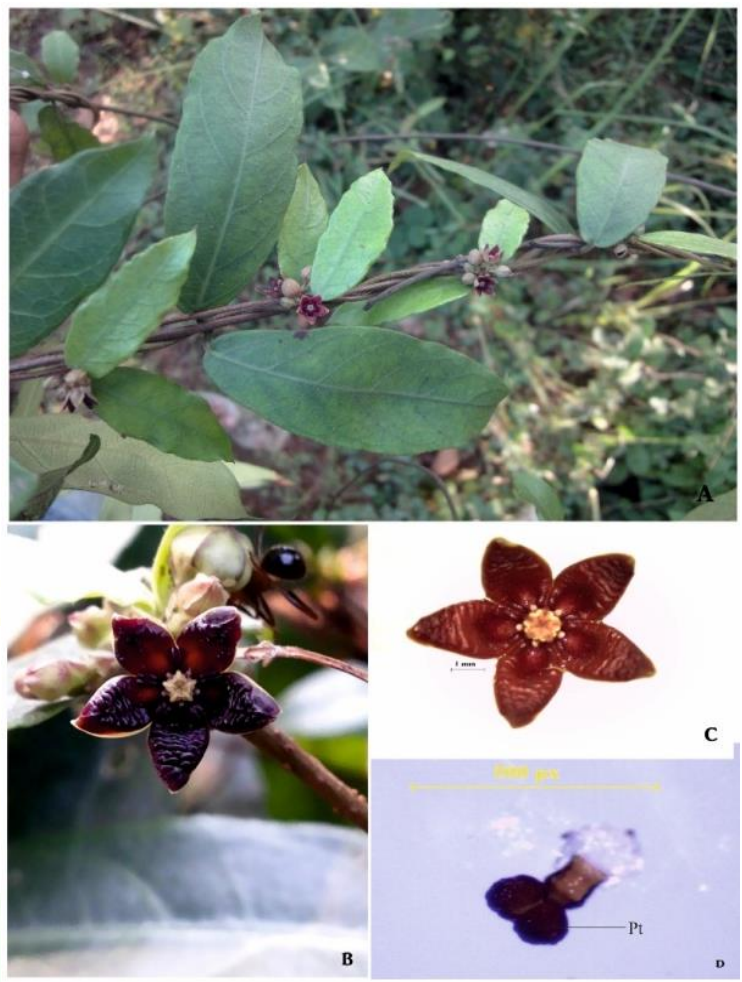

Fig. 12: Hemidesmus indicus A. Flowering twig, B. single flower, C. LM image of Flower, D. LM image of pollen tetrad with translator

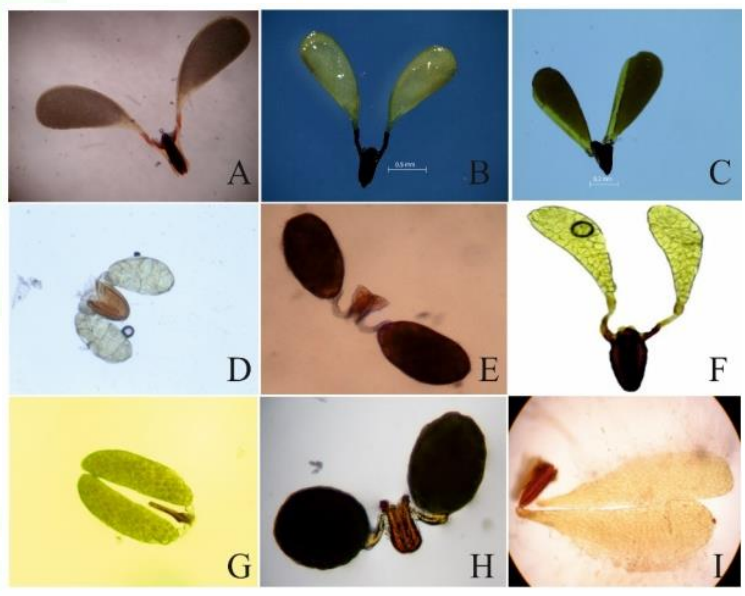

Fig. 13: Light microscopic image of pollinarium of 9 selected plant taxa of Asclepiadaceae, A. Pollinarium of Calotropis gigantea (L.) W.T. Aiton., B. Pollinarium of Calotropis procera (Aiton) W.T. Aiton. C. Pollinarium of Daemia extensa (Jacq.) R.Br., D. Pollinarium of Gymnema sylvestres R.Br.E. Tylophora tenuis Blume., F. Pollinarium of Holostemma ada-kodien Schult., G. Pollinarium of Dregea volubilis (Linn.f.) Benth., H. Pollinarium of Tylophora indica (Burm.f.) Merr. and I. Pollinarium of Oxystelma esculentum (L.fil.) R.Br.

\section{Cluster-IV}

All the species of this cluster are characterized by relatively large size of pollinium sac. The length of pollinium sac is relatively short in Dregea volubilis than other two species of Calotropis. The size, shape, orientation of pollinium sac and translator attachment to the pollinia is more or less same in the two species of Calotropis but they are differing in their size of breadth of corpusculum. 


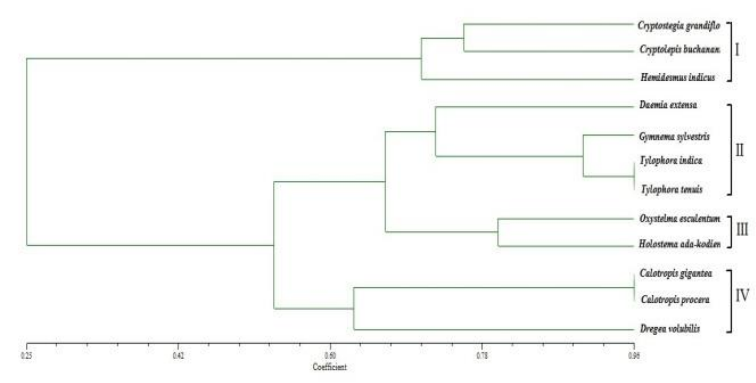

Fig. 14: Dendrogram based on UPGMA analysis NT SYSpc var 2.2 of 12 selected plant taxa under the family Asclepiadaceae

\section{Conclusion}

The phylogenetically explicit approach adopted in this study provides a preliminary analysis of the timing and patterns of diversification of these structures, as well as an assessment of the level of homoplasy. Although homology assessments and evolutionary reconstructions for these structures have been presented in the past, regor has been limited by the lack of an explicit phylogenetic hypothesis (Good, 1956; Kunze, 1990, 1995; Swarupanandan et al., 1996; Endress and Bruyns, 2000) or minimal taxon sampling and attention to topological ambiguity and homology decisions (Wanntorp, 1988). Admittedly, taxon sampling in the present study is still inadequate to fully explore the range of corona evolution of Asclepiadaceae and the origin of pollinia in Periplocoideae, subjects still ripe for further investigation. Under some scenarios, the origin of subfamilies and tribes may be marked by large changes in corona morphology with no subsequent homoplasy e. g., the synapomorphic loss of coralline coronas in Asclepiadoideae. In other cases, homoplasy is inferred regardless of homology assessment, as in the convergence and loss of gynostegial coronas of Asclepiadeae. The greater degree of homoplasy in coronas than pollinaria invites inquiry into adaptive explanations. One could speculate that the greater functional diversity of coronas plays an important role. The sole function of pollinaria is the transfer of male gametes. Coronas may participate in the attraction, reward and positioning of pollinators (Wanntorp, 1974; Kunze, 1991, 1997; Endress, 1994). On the basis of our study it observed that the Asclepiadaceae family divided to three subfamilies viz Periplocoideae, Secamonoideae and Asclepioideae as well as the Subfamily Asclepeoideae again divided to three tribes which are Tylophorineae, Oxystelmineae and Calotropineae.

\section{Acknowledgement}

I am highly acknowledging to all of the research scholars of the Plant Taxonomy, Biosystematic and Molecular Taxonomy Laboratory; UGC-DRS-SAP Department, Department of Botany \& Forestry, Vidyasagar University, Midnapore-721102, West Bengal, India. I am also grateful to Technical staffs of a University Science Instrumentation Centre (USIC), Vidyasagar University as well as Burdwan University, IIT Kharagpur and Bose Institute, Kolkata.

\section{References}

1. Bentham, G. "Notes on Orchideae." Journal of the Linnean Society of London, Botany 18(1881): 281-360.

2. Bookman, S.S. "The floral morphology of Asclepias speciosa (Asclepiadaceae) in relation to pollination and a clarification in terminology for the genus". American Journal of Botany. 68(1981): 675-679.

3. Brown, R. "On the Asclepiadaceae, a natural order of plants separated from the Apocynaceae". Hussien. Mem. Wern. Nat. Hist. Soc. 1(1811): 12-78
4. Bullock, A.A. "Notes on African Asclepiadaceae". Bull.Kew. 11(1956):503525 .

5. Civeyrel, L., Thomas, A. Le., Ferguson, K. and Chase, M. W. "Critical reexamination of palynological characters used to delimit Asclepiadaceae in comparison to the molecular phylogeny obtained from plastid matK sequences" Molec. Phylogenet. Evol. 9(1998):517-527

6. Corry, T.H. "On the structure and development of the gynostegium, and the mode of fertilization in Asclepias cornuti, Decaisne (A. syriaca L.) Trans". Linn. Soc. London, Bot. 2(1883):173-207

7. Endress, M.E. and Bruyns, P. "A revised classification of the Apocynaceae sens. Lat". Botanical Review (Lancaster) 66(2000): 1-56.

8. Endress, M.E., Liede-Schumann, S. and Meve, U. "Advances in Apocynaceae: the enlightment, an introduction". Annals of the Missouri Botanical Garden. 94(2007): 259-267.

9. Endress, M.E. Diversity and evolutionary biology of tropical flowers; Cambridge: Cambridge University Press. (1994).

10. Fallen, P.K. "Floral structure in the Apocynaceae: morphological, functional, and evolutionary aspects". Botanische Jabrbu"cher für Systematic. 106(1986): 245-286.

11. Franks, J.W. and Watson, L. "The Pollen Morphology of some critical Ericales". Pollen ET Spores, 5(1963): 51-68.

12. Good, R. "Features of Evolution in the Flowering Plants". Longman Green Co, London (1955):

13. Hutchinson, J. "Evolution and Phylogeny of flowering Plants". Academic Press (1969): (London and New York)

14. Kunze, H. "Morphogenese and Synorganization des Besta" ubungsapparates einiger Asclepiadaceen". Beitra"ge zur Biologie derPflanzen. 56(1981): 133-170.

15. Kunze, H. "Structure and function in asclepiad pollination". Plants Systematics and Evolution. 176(1991): 227-253.

16. Kunze, H. "Floral morphology of some Gonolobeae (Asclepiadaceae)". Botanische Jabrbucher fur Systematik. 117(1995): 211-238.

17. Kunze, H. "Morphology of the stamen in the Asclepiadaceae and its systematic relevance". Botanische Jabrbucher fur Systematik, 118(1996): 547579

18. Kunze, H. "Corona and nectar system in Asclepiadinae (Asclepiadaceae)". Flora, 192(1997): 175-183

19. Kunze, H. "Morphology and evolution of the corona in Asclepiadaceae and related families". Trop Subtrop Pflanzenwelt. 76(1999): 1-51

20. Kunze, H. Floral Morphology of some Gonolobeae (Asclepiadaceae). But.Jabrb.syst. 117(1995): 211-238.

21. Nilsson, S., Endress, M.E. and Grafstrom, E. "On the relationship of the Apocynaceae and periplocaceae”. Grana suppl. 2(1993): 3-20.

22. Safwat, F. "The floral morphology of Secamone and the evolution of pollinating apparatus in Asclepiadaceae". Annals of Missouri Botanical Garden. 49(1962): 95-129.

23. Santapau, H. and Irani, N, A. "The Asclepiadaceae and Periplocaceae of Bombay". Bot. Mem., 4(1962): University of Bombay.

24. Swarupanandan, K., Mangalym, J. K., Sonny, T. K., Kishorekumar, K. and Vasga, S.C. "The subfamilial and tribal classification of the family Asclepiadaceae". Bot. J. Linn. Soc. 120(1996): 327-369

25. Verhoeven, R.L. and Venter, H.J.T. "Pollen morphology of the periplocaceae from Madagasca” r. Grana 33(1994): 295-308.

26. Wanntrop, H.E. "Calotropis gigantean (Asclepiadaceae) and Xylocopa tenuiscapa (Hymenoptera, Apidae). Studies in flower morphology and pollination biology". Svensk Bot.Tidskr. 68 (1974):25-32.

\section{Cite this article as:}

Sanjit Sinha and Amal Kumar Mondal. A phylogenetic study of floral morphology of some members of Asclepiadaceae R.Br. Annals of Plant Sciences 6.02 (2017): 1546-1556.

DOI: http://dx.doi.org/10.21746/aps.2017.02.004 